\title{
EFEKTIVITAS KEGIATAN BERMANFAAT PEMUDA MAHASISWA DALAM MENGISI MASA MUDA DIKEHIDUPAN SEHARI-HARI
}

\author{
Nur Rahmat \\ Program Studi Psikologi Fakultas Kedokteran Universitas Lambung Mangkurat, \\ JL.A Yani, 36.00 Banjarbaru Kalimantan Selatan, 70714, Indonesia \\ Nurrahmathabsyi22@gmail.com
}

\begin{abstract}
Dalam penelitian dan pengamatan yang dilakukan pada fokus objek para remaja dan dewasa, terutama mahasiswa yang ada di Kalimantan Tengah dan Kalimantan Selatan. Kebiasaan dan kegiatan yang dilakukan dalam berproses mengejar impian dan cita-cita. Metode yang dilakukan adalah observasi. Dimana melakukan pengamatan kebiasaan para mahasiswa dan pemuda lainnya di kehidupan sehari-hari. Hasil yang ditemukan ternyata banyak sekali efektivitas kegiatan mahasiswa dan pemuda lainnya yang bermanfaat bagi dirinya dan masa depan. Tentunya ini merupakan suatu hal yang positif dari proses para pemuda untuk menggapai cita-cita dan impiannya, serta mengisi perjalanan hidupnya dengan pengalaman yang positif.
\end{abstract}

Keywords : Pemuda, Mahasiswa, Efektivitas

\section{PENDAHULUAN}

Masa muda merupakan masa dimana setiap individu berlomba mencari jati diri dan melatih diri untuk mencapai masa depan yang lebih baik. Tingkat ambisiusnya untuk mencapai sesuatu itu tinggi. Mengeksplorasi diri menjadi hal yang sebagian besar dilakukan para pemuda. Bagi para mahasiswa dan pemuda lainnya lebih mengisi masa mudanya ke hal-hal yang positif dan mengikuti organisasi. Sebab sudah mampu memilih mana yang baik bagi dirinya dan mana yang tidak. Lingkungan dan pergaulan juga memiliki peran dalam perkembangan dimasa muda. Membangun interaksi sosial dan memperbaiki komunikasi agar terjalinnya suatu hubungan yang baik dengan orang sekitar. Mencari sebanyak mungkin relasi yang bermanfaat bagi dirinya. Mencari regulasi pembelajaran diri yang efektif serta bermanfaat untuk masyarakat. Ini merupakan pemikiran dari pemuda yang sebelumnya telah menempuh pendidikan. Beda dengan pemuda yang sama sekali tidak pernah menempuh pendidikan atau berhenti ditengah jalan. Pemilkirannya akan selalu bekerja dan mendapatkan uang, tidak begitu peduli dengan karirnya dimasa depan. Karakteristik dimasa dewasa sungguh jauh berbeda dengan masa kecil. Berpikir terus menerus untuk menghadapi dan memecahkan masalah yang selalu berdatangan. Dibandingkan dengan masa kanak-kanak yang tidak terlalu serius dalam menghadapi masalahnya. Diusia remaja menuju dewasa gaya hidup juga menjadi perhatian bagi para pemuda. Dunia sosial media menjadi sarana yang lebih sering diakses. Sikap sukarela membantu dan beramal menjadi agenda religi yang dilakukan para pemuda sebagai bentuk kepedulian terhadap sesama. Dorongan dari orang tua dan keluarga juga menjadi pengaruh semangatnya jiwa untuk menggapai sesuatu dalam dirinya. Peran orang tua dalam mendukung anaknya, akan memberi warna dan motivasi secara moral. Walaupun tidak 
semuanya para pemuda mendapat dukungan moral dari orang tua. Sebagian pemuda akan tetap melanjutkan apa yang diinginkannya sebagai pembuktian kepada orang tuanya. Masa dewasa bukanlah lagi masa untuk bersantaisantai, menunggu suapan nasi dari orang tua. Difase inilah para pemuda akan mengadu dan menentukan nasibnya. Tentunya semua pemuda ingin masa depannya menjadi sukses, hidup berkecukupan dan mandiri. Jalan yang ditempuh pun beragam. Ada yang melanjutkan pendidikan dengan berkuliah di Universitas impian, mendaftar kedinasan, ada yang langsung bekerja, dan ada pula yang kursus lalu bekerja. Dalam ruang lingkup pemuda, pastinya memiliki karakter berbeda-beda. Ada yang memiliki kemampuan dalam memimpin. Insting yang dimiliki anak muda adalah merasa mampu dalam memimpin dirinya sendiri. Sehingga ada sedikit rasa egois dalam dirinya ketika menerima masukkan atau kritikan dari orang lain. Walaupun respon yang diberikan seolah-olah menerima padahal realitanya tidak begitu. Hal ini merupakan fakta, namun dengan adanya pendidikan yang masuk kedalam lingkungan pemuda, mengubah pandangannya menjadi lebih baik. Menjadikan komentar atau nasehat itu sebagai dorongan untuk mengevaluasi diri. Inilah yang dinamakan berproses. Dimasa muda inilah, karakter harus dibentuk. Pemerintah pun gencar mencari alternatif agar para pemuda bangsanya menjadi berguna dan menjadi sumber daya manusia yang unggul dan handal. Kita patut bersyukur, tidak semuanya para pemuda bisa berkuliah, ada yang terkendala ekonomi dan tidak adanya restu dari orang tua.

\section{METODE PENELITIAN}

Populasi dari penelitian ini adalah para mahasiswa dan pemuda lainnya yang ada di Indonesia terkhususnya di Kalimantan Selatan dan Kalimantan Tengah. Dengan melihat berbagai kisah cerita dari para pemuda yang ditayangkan di saluran Televisi atau sosial media menjadi acuan untuk meneliti sebagian besar aktivitas para pemuda ketika berproses yang efektif. Mencari kegiatan pemuda yang bermanfaat dan efektivitas para pemuda dalam mencapai keberhasilan. Teknik metode yang dilakukan adalah observasi, bisa juga dikenal dengan pengamatan. Adler \& Adler (1987 : 389) dalam pandangannya, "Observasi merupakan salah satu dasar fundamental dari semua metode pengumpulan data dalam penelitian kualitatif, khususnya menyangkut ilmu-ilmu sosial dan perilaku manusia". (Werner \& Schoefle, 1987 : 257). "Observasi merupakan proses pengamatan sistematis dari aktivitas manusia dan pengaturan fisik dimana kegiatan tersebut berlangsung secara terus menerus dari fokus aktivitas bersifat alami untuk menghasilkan fakta". Pengamatan yang dilakukan tidak terjun secara langsung dilokasi. Namun mengamati dan memahami dari lingkungan sekitar dan dunia sosial media.

\section{HASIL DAN PEMBAHASAN}

Dalam perkembangan usia, tentunya setiap individu akan mengalami perkembangan fisik maupun psikis. Dari fase kita bayi, kanak-kanak, remaja, dewasa, hingga usia tua. Ada yang berkata bahwa masa kecil ( kanak-kanak ) itu mengasyikkan dari pada masa remaja dan dewasa. Itu benar kenyataannya. Sebab dimasa kanak-kanak menjadi tempat untuk memuaskan bermain bersama kawan-kawan. Hal ini berbanding terbalik ketika sudah dewasa. Yang dipikirkan adalah sibuk dengan pendidikan (Mahasiswa ; tugas, penelitian, uts, ujian akhir, dan skripsi), biaya hidup, masa depan, penampilan fisik, dan gaya hidup (gengsi). Banyak yang dicemaskan dan dikhawatirkan. Kehidupan setelah lulus SMA, atsmosfer yang dirasakan jauh berbeda. Sebab kedepannya akan memperjuangkan cita-cita dan impian dimasa depan. Ide-ide dan pemikiran kreatif akan terbentuk ketika berproses. Jalan yang ditempuh setiap pemuda pun berbeda-beda. Ada yang merencanakan melanjutkan kuliah, mendaftar disekolah kedinasan, mendaftar TNI/Polri, langsung bekerja, dan ada yang kursus lalu 
bekerja. Para pemuda akan berlomba-lomba mencari hal yang terbaik agar masa depannya terjamin dan apa yang diinginkan tercapai. Tanggung jawab semakin besar dan nyata untuk menuntaskan cita-cita dan impian. Dimasa dewasa, para pemuda tidak asing lagi dengan namanya masalah hidup. "Karakteristik masa dewasa yang menonjol diantaranya ialah masa dewasa awal yang disebut juga dengan masa bermasalah. Pada awal tahun masa dewasa terdapat masalah baru yang harus dihadapi setiap individu yang menuntut tanggung jawab. Perubahan individu banyak mengalami beberapa perubahan secara fisik, kognitif, maupun psikososio-emosional untuk menuju kearah kepribadian yang lebih matang dan bijaksana" Tidak dapat dipungkiri, masa dewasa merupakan masa untuk berproses, dimana belajar untuk menghadapi masalah dan menyelasaikan masalah. Bagi yang tidak siap mental, dia akan selalu mengeluh. Banyak yang berkata berani bergerak keluar dari zona nyaman. Maksudnya adalah kita mengupgrade diri, mencari hal-hal baru dan pengalaman yang baru, serta sesuatu yang sebelumnya tidak pernah dicoba. Kesalahan dan kegagalan itu pasti ada, namun hal itu bukan menjadi alasan untuk berhenti. Karena setiap pemuda yakin bahwa jalan untuk bangkit pasti ada. Suatu masalah yang dihadapi, bisa dijadikan sebagai guru spritual bagi diri, agar terus belajar dan memperbaiki diri. Sebagian besar pemuda akan mengisi kegiatan pada hal-hal yang positif dan memberi dampak baik bagi diri, karena pendidikan sebelumnya telah ditanamkan pada karakter setiap remaja agar mampu berpikir mana yang baik bagi dirinya untuk masa depannya. Tentunya para pemuda yang memiliki akal pikiran yang baik akan menghindari hal-hal yang negatif yang akan merusak dirinya. Fenomena sosial yang ada dikalangan para remaja dan dewasa adalah pergaulan yang keliru. Hal ini yang akan membawa pada pemikiranpemikiran yang salah. Bisa jadi karena keadaan ekonomi yang tidak stabil akan membawa kearah yang tidak baik. misalnya mencuri, meminum tuak atau alkohol, memakai narkoba, seks bebas, dan tawuran. Ini adalah beberapa aktivitas yang keliru oleh pemuda saat ini. Hal ini akan menjadi paradigma perbedaan perbandingan dengan sebagian besar pemuda yang memiliki karakter intelektual baik dan positif. Tentunya lingkungan juga berpengaruh bagi perkembangan diri, terutama para pemuda. Sebuah lingkungan dapat memberikan dampak yang baik dan buruk bagi manusia. Begitu juga sebaliknya, manusia juga dapat memberikan dampak yang baik ataupun buruk bagi lingkungan. "Interaksi antara manusia dengan lingkungan hidup sekitar dapat memicu timbulnya berbagai masalah dalam kehidupan sehari-hari"2. Masalah yang timbul bisa positif ataupun negatif. Tergantung interaksi yang dibangun. Lingkungan yang baik dapat menjadi promotor bagi individu untuk berkembang dengan baik. Sepakat bahwa lingkungan dapat mempengaruhi jiwa mental terutama pemuda. Sebaliknya, manusia juga dapat memberikan dampak yang buruk bagi lingkungan. Karena berbagai macam karakter dalam diri manusia, ada yang berjiwa perusak dan ada juga yang merawat. Dalam hal ini para pemuda-pemuda mahasiswa berusaha melakukan upaya terhadap perawatan lingkungan. Karena dalam lingkungan yang baik, pastinya akan memberikan dampak yang baik pula. Para mahasiswa juga mempunyai organisasi-organisasi yang bergerak dibidang penjagaan lingkungan, terutama bagi mahasiswa Fakultas Kehutanan. Ini merupakan kegiatan yang real dari para pemuda mahasiswa dalam lingkup pendidikan yang bersifat bermanfaat dan efektivitas. Para pemuda lainnya (selain mahasiswa), juga memiliki komunitas-komunitas atau club-club yang dibentuk, sebagai kepedulian terhadap lingkungan. Kegiatan yang konteksnya bersifat efektivitas sangat diperlukan dan harus dilakukan oleh para pemuda dalam berproses. Lingkungan bagi para pemuda, khususnya mahasiswa akan berlomba mengejar prestasi dan mengisi kegiatannya dengan hal-hal yang bermanfaat. Berjumpa dengan orang-orang baru dan orang-orang hebat menjadi kesempatan bagi diri untuk menambah relasi dan lingkaran pertemanan. Interaksi komunikasi secara sosial 
sangat diperlukan bagi para mahasiswa. Dengan adanya interaksi, sebuah hubungan dengan orang lain dan lingkungan sekitar akan terjalin dengan baik. Pada dasarnya, jati diri manusia itu bersifat sosial, yang artinya bahwa, manusia tidak bisa hidup sendiri, pasti membutuhkan orang lain. Sudah dipastikan akan terjadi kontak komunikasi terhadap sesama. Hal ini tentunya telah diajarkan dalam ilmu Sosiologi. "Salah satu kebutuhan manusia adalah berinteraksi dengan orang lain dilingkungan sekitar. Interaksi sosial merupakan hubungan sosial yang dinamis untuk menjalin hubungan sosial"3. Saat ini sarana komunikasi yang paling banyak digunakan dan sedang trend dikalangan remaja dan dewasa yaitu sosial media. Tak hanya orang-orang yang dewasa, bahkan anak-anak pun sudah mengenal yang namanya gadget. Sarana komunikasi yang satu ini sangatlah praktis. Bermodalkan internet yang lancar dan kuota, maka anda bisa berselancar didunia sosial media. Hal ini tentunya menjadi problem dimasyarakat. Ada yang berpendapat bahwa, sosial media lebih membawa dampak negatif bagi penggunanya. Namun disatu sisi, sosial media juga dapat memberikan dampak yang baik. Dengan majunya teknologi, semakin memudahkan manusia dalam beraktivitas. Hal ini tentunya membuat para mahasiswa dan pemuda kreatif lainnya memanfaatkan teknologi ini dengan baik. Ide-ide kreatif yang muncul dari para pemuda menimbulkan edukasi dan hal yang positif. Misalnya membuat lomba secara online, membuat vidio edukasi, melakukan webinar yang bermanfaat, pelatihan keterampilan dan masih banyak lagi yang lainnya. Masa muda tentunya memiliki sikap ego yang tinggi. Mereka akan mencoba sesuatu hal yang mana mereka pun sebenarnya tahu kemampuan mereka sendiri, namun tetap gigih mencoba. Misalnya, kemampuannya seorang pemuda adalah didunia otomotif. Namun karena dunia seni lebih menjanjikan bagi karirnya, ia pun akan menggeluti hal tersebut dengan kemampuan yang tidak begitu baik dikuasainya. Hal itu sebenarnya, ia telah menyadarinya bahwa hal itu akan menjadi prioritas masalahnya. Namun karena sifat ambisius yang tinggi ia akan mengikuti egonya. Inilah hal yang biasa kita temukan pada pemuda. Karena memiliki waktu hidup yang banyak dalam artian kesempatan memanfaatkan peluang dan pikiran yang masih fresh, mindset seperti inilah yang menjadi paradigma bagi para pemuda ingin mencoba semua hal. Tindakan yang dilakukan berdasarkan atas kehendak diri. Ketika memasuki dunia mahasiswa, para pemuda akan belajar banyak hal dalam dunia pendidikan. Mengikuti setiap organisasi sesuai minat dan kemauannya. Berbagai karakter yang baik ditanamkan kepada mahasiswa. Tentunya ini merupakan bekal bagi para mahasiswa untuk menerapkannya saat terjun dimasyarakat. Menolong terhadap sesama dan membantu tanpa mengharapkan imbalan. Hal ini disebut juga dengan Altruisme. "Altruisme merupakan tindakan yang bersifat sukarela yang dilakukan oleh seseorang atau sekelompok orang untuk menolong orang lain tanpa mengharapkan imbalan apapun"4. Hal inilah yang diharapkan sistem pendidikan moral di Indonesia. Dimana karakter kepribadian yang berakhlak baik. Para mahasiswa sebelumnya telah diajarkan tentang adab membantu orang lain. Bahkan saat duduk dibangku SD pun sudah diajarkan. Jika dalam kegiatan mahasiswa, kegiatan ini dinamakan baksos. Disinilah tempat para pemuda melakukan amal atau pun kegiatan yang membantu orang lain serta menjalin silaturahmi. Salah satu pengabdian mahasiswa pada masyarakat. Tak hanya itu biasanya ketika terjadi bencana disuatu daerah, mereka akan bergerak dengan membentuk relawan untuk mengumpulkan donasi. Dimasa muda inilah ajang untuk mengikuti organisasi-organisasi yang dapat membentuk karakter. Sejatinya setiap orang adalah pemimpin. Pemimpin dalam artian mampu memimpin dirinya sendiri. Para pemuda memiliki kemampuan intelektual yang dapat dikembangkan dalam memimpin. Sebagian besar dari pemuda lebih suka dalam memimpin atau menjadi leadership. Berkaca dari pandangan para pemuda, menjadi seorang pemimpin itu keren dan pastinya penuh tantangan. Sebab para 
pemuda sangat menyukai tantangan. Dimasa muda inilah karakter dan keahlian dalam memimpin dapat dibentuk. "Setiap orang adalah pemimpin. Kepemimpinan yang baik adalah orang yang mampu dan bisa mempengaruhi pihak lain maupun komunikasi langsung atau tidak langsung dengan maksud untuk menggerakkan orang-orang dengan pengertian, kesadaran, dan senang hati bersedia mengikuti kehendak pemimpinnya"5. Tentunya sesama pemuda kita tahu bahwa, anak muda itu sensitif dalam menerima komentar dari orang lain. Maka dari itu perlu adanya latihan dalam memimpin seseorang. Mengikuti pelatihan kepemimpinan dan mengikuti program-program talkshow atau webinar yang membahas tentang leadership. Bisa juga langsung mengamati pejabat-pejabat yang memiliki sikap karismatik dan bijaksana dalam memimpin. Mencetak diri menjadi pemimpin yang berkualitas, akan mudah bagi diri dalam menyesuaikan lingkungan dimana pun berada. Biasanya ketika mengikuti organisasi-organisasi yang berada dikampus, akan membentuk kemampuan diri. Secara tidak langsung belajar secara bertahap dalam melatih skill diri. Menjadi seorang pemimpin bagi seorang pemuda bukanlah tempat ajang untuk mencari gaya dan gila hormat. Rata-rata anak muda yang menjadi pemimpin dalam organisasinya, ia lebih melakukan hal yang terbaik bagi organisasinya. Mencoba merangkul dan menjalin kerja sama antara satu orang dengan yang lainnya, menjadi promotor penggerak bagi organisasinya. Semangat yang dimiliki para pemuda adalah semangat yang menggebu-gebu. Jika mengalami sebuah kegagalan, anak muda akan mencari jalan yang lainnya. Selain mengejar prestasi dan mengasah kemampuan diri, sebagian besar pemuda pastinya memiliki selera fashion yang beragam. Masing-masing memiliki kelas sosial tersendiri. Mode pakaian, make up, dan barangbarang mewah menjadi hal yang diinginkan para pemuda. Bahkan ada yang bekerja dengan usahanya sendiri untuk memenuhi semuanya itu. Dalam hal berpakaian, saat ini banyak sekali model-model pakaian yang beragam. Tentunya harganya pun terbilang tidak murah. Dengan memutar otak, para pemuda akan mencari cara untuk mendapatkan apa yang ia inginkan. Ada yang minta uang dengan orang tua dan ada juga yang mencari uang dengan usahanya sendiri. Fenomena pakaian yang kebanyakan disukai para pemuda adalah pakaian yang terbuka. Sebab dengan berpakaian seperti itu akan dirasa sebagai orang yang gaul. Menggunakan celana yang pendek, ketat, dan ada yang dengan mode sobeksobek di celananya, terutama celana jeans. Hal inilah yang bertentangan dengan moral dalam berpakaian. Dalam agama Islam telah diajarkan bahwa berpakaianlah yang mampu menutup auratmu. Sebab jika kita mampu menutup aurat, tidak akan timbul pikiran-pikiran negatif ketika orang lain yang melihat. Terutama kepada wanita. Dalam hal berpakaian sudah sepatutnya para remaja dan dewasa untuk memilih dan menggunakan pakaian yang sopan pantas. Baik laki-laki maupun perempuan haruslah mampu dan mengupayakan untuk dapat menutup auratnya, sesuai dengan ajaran Islam."Wanita dalam Islam diwajibkan untuk menutup auratnya dari ujung kepala sampai ujung kaki kecuali wajah dan telapak kaki" 6 . Kenapa hal ini sampai diajarkan oleh agama, sebab efek yang ditimbulkan akan memberikan dampak yang baik dan positif bagi dirinya dan lingkungan sekitar. Ada beberapa sebagian pemuda terutama wanita yang mengedukasi dalam berpakaian dan berhijab. Bahkan ada juga yang merancang busana pakaian nuansa Islam. Tak hanya itu ada juga yang membuat tutorial berhijab. Ini merupakan langkah dari sebagian pemuda khususnya wanita untuk menyadarkan dan memberikan edukasi kepada sesame wanita lainnya. Bahkan hijab sekarang sedang trend dikalangan remaja dan dewasa. Buktinya dengan berbagi macam model busana hijab yang diperkenalkan. Selain sebagai fungsi menutup aurat, sebagian wanita menambahkan estetika dalam hijab, agar nampak indah dan cantik ketika digunakan. Selain berkenaan dengan berpakaian tentu anak muda tidak lepas dari yang namanya make up dan perawatan kulit. 
Sebagian besar pemuda, memperrhatikan penampilan dan fisiknya agar terlihat menarik. Disinilah timbul ide-ide sebagian pemuda untuk mempromosikan alat-alat kecantikkan. Mereka paham betul jika soal yang berkaitan dengan perawatan wajah. Jika sampai ada jerawat diwajah, mereka stress dan kurang pede ketika keluar rumah. Mereka akan mencari cara agar jerawat yang ada diwajah dapat hilang. Itu adalah hal yang lumrah bagi pemuda. Mereka tidak akan percaya diri ketika memiliki jerawat. Terlepas dari itu, pemuda-pemuda diseluruh dunia memiliki tujuan hidupnya masing-masing dan bervariasi. Ada yang begitu semangat dan gigih mengejar impiannya, dan ada yang frustasi pula ketika ia terus-menerus gagal. Roda hidup terus berputar, kadang tidak selamanya kita selalu diatas dan tidak selamanya juga kita dibawah. Begitu juga dengan mahasiswa dan pemuda lainnya. Menjadikan perjalanan hidup sebagai ajang untuk mendapatkan pengalaman sebanyak mungkin, dan bercerita kepada anak cucunya kelak tentang perjalanan hidupnya. Ketika menjadi mahasiswa, tentu sebagian pemuda akan berpikir bahwa, ia akan terus melanjutkan pendidikannya sampai mendapat gelar yang diinginkan. Progres yang dilakukan tidaklah mudah. Berbagai rintangan dan masalah harus dihadapi. Ada yang berkata bahwa, masa muda dan dewasa itu tempat banyaknya masalah. Berbagai macam bentuk permasalahan akan menempa diri dan membentuk sebuah karakter baru. Pemuda yang berakal positif, ia akan terus menghadapi masalah dan menyelesaikannya. Bukan menjadi seorang pecundang yang bersembunyi dibalik masalah. Mengubah keluhan menjadi rasa syukur, dan sebuah masalah menjadi bekal pelajaran secara nyata untuk kehidupan selanjutnya. Bagi seorang mahasiswa, akan ditempa berbagai tugas. Tak hanya itu mungkin ada sebagian besar yang berkuliah sambil bekerja. Berbagai macam masalah dan kesulitan akan dihadapi para mahasiswa. Membagi waktu antara aktif berorganisasi dan kuliah. Mengikuti bermacam event atau perlombaan untuk mengasah skil diri.
Dukungan moral dari orang tua sangat mempengaruhi progres anaknya. Dengan adanya semangat dan dukungan moral dari orang tua akan menjadi kebanggan tersendiri bagi anaknya. Tidak semuanya anak mendapatkan dukungan dari orang tua. Notabenenya, para mahasiswa dan pemuda lainnya akan mencari jalan sesuai yang mereka inginkan, tanpa ada paksaan. Ketika telah mendapat restu dan dukungan dari orang tua, maka akan menambah eksistensi dalam menggapai apa yang diinginkan. "Makin besar pengaruh dari orang tua, ternyata memiliki peran yang begitu signifikan sehingga makin besar, maka akan semakin tinggi pula tingkat motivasi prestasi dari mahasiswa"7. Hal ini bukanlah omong kosong semata. Perasaan yang dialami seorang mahasiswa atau pemuda lainnya ketika orang tua mendukung sepenuhnya berbeda dengan pemuda yang lainnya yang tidak mendapatkan dukungan. Secara mental akan membuat pikiran menjadi terbuka dan bergerak dengan leluasa. Mahasiswa perlu adanya dukungan moral dari orang tuanya agar cepat menyelesaikan skripsinya. "Regulasi diri pada setiap orang (pemuda/mahasiswa) dipengaruhi oleh karakteristik tiap individu yang bersangkutan. Regulasi diri dalam belajar yang dilakukan tidak terlepas dari dukungan sosial dan moral"8. Sistem pembelajaran yang diterapkan kepada para mahasiswa berbeda-beda dan tingkat stres yang dialami pun bervarisi. Apalagi pembelajaran daring yang dilakukan saat ini. Sebagian besar mahasiswa akan mengalami berbagai kesulitan, terutama pada jaringan. Tidak semuanya merata dengan jaringan yang baik. Belum lagi ketika memahami materinya. Menatap layar monitor pada laptop dan handphone terlalu lama dapat membuat kepala pusing. Tentunya mahasiswa akan mengulang kembali dan mencari tahu sendiri materi yang telah dipelajari ketika tidak memahami atau mungkin ia terkeluar dari kelas akibat jaringan yang tidak baik saat dosen menjelaskan materi. Identiknya mahasiswa mengenyam pendidikan untuk menerapkannya dalam kehidupan seharihari. Masalah sosial yang ada dimasyarakat, 
tentunya mahasiswa memiliki hak untuk ikut andil dalam menyelesaikan masalah. Saat itulah tindakan nyata dari mahasiswa ditampilkan. "Sumber belajar dalam pembelajaran sosial harus dilihat sebagai kesatuan yang utuh dalam proses pembelajaran. Sebuah pembelajaran yang efektif perlu dilakukan kemudian diterapkan pada masyarakat"9. Pembelajaran sosial yang efektif, diharapkan mampu merubah pola pikir para mahasiswa agar mampu ikut campur dalam masalah dimasyarakat. Jika terjadi kisruh tentang peraturan dinegeri, para mahasiswa dapat ikut andil dan berpatisipasi dalam hal itu. Kegiatan mahasiswa tentunya beragam. Mungkin ini dirasakan para mahasiswa diseluruh Univeritas di Indonesia. Misalnya ada yang belajar dalam menulis novel, cerpen, jurnal, ataupun essay. Hal itu tentu bukanlah suatu hal yang mudah. Perlu waktu untuk menguasai dan dapat diterima dimasyarakat. Kita ambil contoh dalam menulis suatu artikel. Menulis bagi sebagian pemuda dan mahasiswa adalah hal yang sulit. Karena butuhnya pemahaman tentang apa yang dikaji. Tak hanya itu peran otak sangat diperlukan untuk menampung informasi yang didapat. Selain otak alat pancaindera seperti pendengaran dan penglihatan juga ikut berperan penting dalam menulis. Otak diibaratkan seperti tempat menyimpan data. "Menulis diotak merupakan tempat untuk menyimpan informasi apapun yang didapat dan dipindai melalui pancaindera" ${ }^{\text {. }}$. Tentu informasi yang didapat akan diproses terlebih dahulu agar hasil yang didapat tidaklah keliru. Kegemaran membaca buku akan sangat membantu dalam menulis. Dengan gemarnya membaca buku, akan memperluas ruang pengetahuan dan bahan untuk menulis. Tentunya dalam hal menulis tidaklah mudah, butuh waktu dan proses. Sekarang bisa kita lihat, ada sudah sebagian dari mahasiswa dan pemuda lainnya yang telah memiliki karya tulis dan bahkan menerbitkan buku hasil karyanya. Entah itu suatu novel, cerpen, kajian dan sebagainya. Ini merupakan eksistensi dari beberapa pemuda yang menekuni hobinya. Tentu semua itu butuh waktu dan jatuh bangun untuk mendapatkan hasil akhir yang membanggakan. Dari beberapa pembahasan diatas, merupakan berbagai macam kegiatan yang bersifat efektivitas dari pemuda (mahasiswa/lainnya) dalam tangga berproses dan mengisi lembar-lembar pengalamannya dalam mencapai apa yang diinginkan. Lebih mengikuti kehendak yang berasal dari diri sendiri, mengikuti egonya dan tidak menyukai adanya paksaan, karena itu sama saja membatasi diri untuk mengekplorasi diri. Dukungan dari orang tua sangat berperan.

\section{SIMPULAN}

Metode observasi yang dilakukan merupakan pengumpulan data dengan pengamatan dan pemahaman. Observasi memudahkan untuk mendapatkan informasi dari penelitian yang diamati. Adapun kajian objek yang diamati adalah para pemuda (mahasiswa/lainnya). Dengan karakter jiwa yang menggebu-gebu, para pemuda berlomba untuk menggapai cita-cita dan impian dengan jalan yang beragam. Tentunya dengan mengisi hari-harinya dengan kegiatan yang bermanfaat dan efektivitas. Kegiatan yang efektivitas merupakan kegiatan yang mencapai suatu keberhasilan atau sebuah pencapaian. Para pemuda tentunya menginginkan hal yang terbaik bagi dirinya. Dari observasi yang dilakukan, sebagian besar para pemuda akan berjuang untuk menentukan masa depannya. Tentunya masingmasing mempunyai jalan yang berbeda. Ada yang memutuskan untuk berkuliah di Universitas impian, mendaftar di sekolah kedinasan, mendaftar menjadi TNI/Polri, ada yang lulus SMA langsung bekerja, dan ada yang mengikuti kursus atau pelatihan terlebih dahulu baru kemudian bekerja. Para pemuda tidak bisa dipaksakan. Mereka akan lebih menuruti egonya dan akan bergerak sesuai dengan apa yang ingin mereka capai. Jika mendapat paksaan, tentu sebagian pemuda akan memberontak sebagai respon ketidaksetujuannya. Permasalahan ketika beranjak dewasa akan terus berdatangan dan akan menghampiri. Para pemuda akan dituntut dalam menyelesaikan masalahnya. Melakukan 
lebih banyak interaksi dengan orang lain untuk mendapatkan relasi dan ilmu dari orang lain. Membangun hubungan interaksi yang baik, akan menambah kemampuannya dalam tampil didepan umum. Mengikuti berbagai macam organisasi yang ada untuk melatih kemampuan diri. Tentunya para pemuda identik dengan calon pemimpin. Ada banyak para pemuda yang memiliki keahlian dalam memimpin. Ini merupakan aktivitas yang sangat efektif bagi pemuda dalam mencapai karir hidupnya. Bahkan menorehkan catatan prestasi ketika berada diruang lingkup kampus. Sikap peduli terhadap sesama tidak luput dari tindakan para pemuda, terutama para mahasiswa. Dengan membentuk organisasi-organisasi yang bergerak dibidang kepedulian terhadap sesama. Mereka akan belajar dan melatih diri untuk membantu tanpa mengharapkan imbalan apapun. Mengikuti perkembangan zaman, dengan pola hidup bergaya sosial mulai dari sosial media, gaya pakaian dan bahasa. Namun sebagian besar pemuda yang memiliki kesadaran akan memanfaatkannya untuk suatu keterampilan dan usaha. Dalam perkuliahan, para mahasiswa menghabiskan waktunya dengan kelas kuliah dan mengikuti organisasi yang melatih diri. Serta mengkuti pelatihan-pelatihan dan edukasi seperti webinar. Mengikuti lomba dan belajar membuat karya tulis. Melakukan regulasi pembelajaran diri yang bermanfaat. Belajar mengatur waktu sebaik mungkin. Sebagian besar mahasiswa ada yang kuliah sambil bekerja untuk membantu orang tua dalam membayar uang kuliah. Banyak sekali ternyata efektivitas kegiatan mahasiswa dan pemuda lainnya yang bermanfaat bagi dirinya dan masa depan. Peran orang tua sangat berpengaruh untuk moral dan psikis pada karaketer jiwa anaknya. Hal itu akan dijadikan dorongan yang positif bagi anak dalam meraih cita-cita dan impiannya.

\section{DAFTAR PUSTAKA}

Adler, Patricia A., \& Adler, Peter, Membership Roles in Field Research, Newbury Park, CA: Sage Publication, 1987

Warner Oswald, \& Schoepfle, G. Mark, Systematic Fieldwork: Ethnographic Analysis and Data Management, Journal of Ethnographic Analysis and Data Management, Vol. 1, Julie Ahern: Sage Publication, 1987, hlm. 1-15.

[ 1 ] Afnan, A., Fauzia, R., \& Tanau, M. U. (2020). HUBUNGAN EFIKASI DIRI DENGAN STRESS PADA MAHASISWA YANG BERADA DALAM FASE QUARTER LIFE CRISIS. Jurnal Kognisia: Jurnal Mahasiswa Psikologi Online, 3(1), 23-29.

[ 2 ] Afnan, A., Fauzia, R., \& Tanau, M. U. (2020). HUBUNGAN EFIKASI DIRI DENGAN STRESS PADA MAHASISWA YANG BERADA DALAM FASE QUARTER LIFE CRISIS. Jurnal Kognisia: Jurnal Mahasiswa Psikologi Online, 3(1), 23-29.

[ 3 ] Aridarmaputri, G. S., Akbar, S. N., \& Yuniarrahmah, E. (2016). Pengaruh jejaring sosial terhadap kebutuhan afiliasi remaja di program Studi Psikologi Fakultas Kedokteran Universitas Lambung Mangkurat. Jurnal Ecopsy, 3(1).

[ 4 ] Kamilah, C., \& Erlyani, N. (2017). Gambaran altruisme anggota komunitas 1000 guru kalimantan selatan. Jurnal Ecopsy, 4(1), 33-40.

[ 5 ] Saputra, H., Febriana, S. K. T., \& Akbar, S. N. (2017). Pengaruh Peran Kepemimpinan terhadap Perilaku Pro-Lingkungan pada anggota organisasi Mahasiswa Pecinta Alam (MAPALA) Piranha. Jurnal Ecopsy, 3(3).

[ 6 ] Arief, M. I., \& Husin, G. M. I. (2019). AGAMA DAN SISTEM PENDIDIKAN NASIONAL (KASUS PELARANGAN JILBAB DI SEKOLAH). Darul Ulum: Jurnal Ilmiah Keagamaan, Pendidikan dan Kemasyarakatan, 171-190. 
[ 7 ] Mayangsari, M. D. (2016). Motivasi Berprestasi Mahasiswa Ditinjau dari Penerimaan Orangtua. Jurnal Ecopsy, 1(1).

[ 8 ] Rachmah, D. N. (2020). Cek Plagiasi: regulasi diri dalam belajar mahasiswa berperan banyak.

[ 9 ] Subiyakto, B., \& Mutiani, M. (2019). Internalisasi nilai pendidikan melalui aktivitas masyarakat sebagai sumber belajar ilmu pengetahuan sosial. Khazanah: Jurnal Studi Islam dan Humaniora, 17(1), 137-166.

[10] Abbas, E. W. (2020). Ersis Writing Theory: Cara Mudah Menulis. 